\title{
Seed Biopriming Using Rhizobacterial Isolated Mixture on Increasing Growth and Yield of Shallots (Allium ascalonicum L.)
}

\author{
G. A. K. Sutariati ${ }^{1 *}$, T. C. Rakian ${ }^{1}$, Muhidin ${ }^{1}$, A. Madiki ${ }^{1}$, C. K. Aji ${ }^{1}$, La Mudi ${ }^{1}$, Andi \\ Khaeruni $^{2}$, Gusti Ngurah Adhi Wibawa ${ }^{3}$, Musadia Afa ${ }^{4}$
}

\author{
${ }^{1}$ Department of Agrotechnology, Agriculture Faculty, University of Halu Oleo, Kendari Southeast Sulawesi, Indonesia, \\ Telp/Fax: +624013191692 \\ ${ }^{2}$ Department of Plant Protection, Agriculture Faculty, University of Halu Oleo, Kendari Southeast Sulawesi, Indonesia, \\ Telp/Fax: +624013191692 \\ ${ }^{3}$ Department of Statistics, Math and Science Faculty, University of Halu Oleo, Kendari Southeast Sulawesi, Indonesia, \\ Telp/Fax: +624013191692 \\ ${ }^{4}$ Department of Agrotechnology, Agriculture Faculty, University of Sembilanbelas November, Kolaka Southeast \\ Sulawesi, Indonesia, Telp/Fax: +6204052321132 \\ *Corresponding author.Email: sutariati69@yahoo.co.id
}

\begin{abstract}
Shallot is very potential to be developed in Southeast Sulawesi, but its productivity is very low, so it needs technological innovation, including the use of microbes as a promoter of plant growth. This study aims to evaluate the effectiveness of shallots seed biopriming using a mixture of rhizobacterial isolates to increase the growth and yield of shallots. This research was conducted at the Experimental Garden II, Faculty of Agriculture, University of Halu Oleo. The experiment was arranged using a Randomized Block Design (RBD), consisting of 8 treatments seed biopriming using a mixture of rhizobacterial isolates, ie without rhizobacterial isolates as control, CKD061 isolate, W2R06 isolate, TWB11 isolate, CKD061+W2R06 isolate, CKD061+TWB11 isolate, W2R06+TWB11 isolate, and CKD061+TWB11+W2R06 isolate. Data were analyzed using variance analysis, followed by Honestly Significant Difference test (BNJ). The results showed that Inoculation of shallots seeds with rhizobacteria both single and mixed was more able to increase the growth and yield of shallots compared to controls. CKD061 single isolate showed better performance in increasing the growth and yield of shallots compared to other controls and isolates, but was not significantly different from mixture of CKD061 + W2R06 isolates. Increased production in the biopriming treatment of CKD061 isolates and CKD061 + W2R06 isolates respectively reached $67.69 \%$ and $53.85 \%$ compared to controls. Further testing is needed on a wider scale to get more consistent results in the field.
\end{abstract}

Keywords: Biopriming, growth, rhizobacteria, seeds, shallots, yield

\section{INTRODUCTION}

The potential for shallot development in Southeast Sulawesi is very large, considering that most of the need for shallots in this area is imported from outside regions such as South Sulawesi and East Java [1]. Until now, only a few districts have developed shallots, including North Kolaka, East Kolaka, Buton and Wakatobi, with an average productivity of only 2.02 tonnes $\mathrm{ha}^{-1}$ [2]. Nationally, Southeast Sulawesi only contributed $0.02 \%$ or 390 tons of the total national production of 1,580,247 tons. The land condition, which is dominated by Red-Yellow Podzolic soil with low fertility, low $\mathrm{pH}$ and low organic matter content, is one of the causes of the low production of shallots in this area. Therefore, various efforts need to be made to increase the carrying capacity of land in shallot cultivation, including through the use of indigenous microbes that can act as biofertilizers. The development of microbial-based biofertilizers is not only done by Indonesia, developed countries in various parts of the world have even started it earlier [3]. In addition, the increasing public awareness in consuming food products that are healthy and free from harmful chemical pesticide residues, has made biofertilizers increasingly in demand. This is certainly a very big opportunity to produce superior microbes that can be used as biofertilizers. The results of previous studies, several potential indigenous microbial isolates (rhizobacteria) from shallot rhizosphere were isolated on marginal land in 
Wakatobi Regency, Southeast Sulawesi, which showed that re-application of these isolates through inoculation on shallot seeds was significantly able to increase viability and vigor. shallot seeds compared to controls [4].

In general, the bacteria isolated from the rhizosphere of the shallot plant were mainly dominated by the Bacillus spp., Serratia spp. group. and Pseudomonas fluorescens, [5]. This type of bacteria has advantages in addition to promote plant growth, it is also able to protect plants from various plant disease infections. Several research results indicate that rhizobacteria are able to synthesize growth hormones, including IAA, gibberellin, and cytokinins [6], [7], [8], fix nitrogen [9], [10], [11] and dissolve phosphate [6], [12]. Meanwhile, as biological controllers for pathogens, rhizobacteria are able to produce compounds or metabolites such as antibiotics, HCN, siderophores, and secrete various hydrolytic enzymes that can degrade pathogenic cells [13], [14], [15].

Each rhizobacterial isolate has a different ability in its function as a growth promoter or biological control for disease. If applied together and both are compatible, it is expected that the advantages of the two isolates will accumulate so that the effect on plants is expected to be better. This study aimed to evaluate the effectiveness of a mixture of rhizobacterial isolates on the growth and yield of shallots.

\section{MATERIALS AND METHODS}

The research was conducted at the Agronomy Unit of the Agrotechnology Laboratory and in the Field Laboratory II of the Faculty of Agriculture, Halu Oleo University Kendari from December 2019 to May 2020

\subsection{Experimental Design}

The experiment was arranged using a randomized block design, consisting of 8 biopriming treatments of shallot seeds using a mixture of rhizobacterial isolates, namely: Control (P0), CKD061 isolate (P1), W2R06 isolate (P2), TWB11 isolate (P3), CKD061 + W2R06 isolates (P4), CKD061 + TWB11 isolates (P5), W2R06 + TWB11 isolates (P6) and CKD061 + W2R06 + TWB11 isolates (P7). Each treatment was repeated 3 times, so that there were 24 experimental units in total.

\subsection{Culture of Isolate and Rhizobacterial Suspension Preparation}

Culture of isolates using TSA media which has been sterilized by autoclave ( $\mathrm{T} 121 \mathrm{oC}, \mathrm{p} 1$ atm, $\mathrm{t} 20$ minutes). One loop of rhizobacteria was scratched quadrant on a $9 \mathrm{~cm}$ diameter petri dish containing TSA media, then incubated at room temperature for 48 hours. The incubated bacterial cultures were then suspended in $100 \mathrm{ml}$ of sterile distilled water in a sterile bottle and in a shaker for homogenization [16]..

\subsection{Seed Treatment by Biopriming of Rhizobacterial Isolates}

The shallot seeds used are local Tomia seeds which have a uniform size (5-10 g per clove). Before being given the treatment, the shallot seeds were washed with running water and wiped with a tissue, then soaked in a suspension of rhizobacteria according to the treatment (seed biopriming). Biopriming of shallot seeds was carried out for 24 hours at room temperature [4].

\subsection{Soil Processing and Planting}

Weeds are cleaned first, then the soil is processed using a hand tractor with a depth of $\pm 30 \mathrm{~cm}$ of tillage. Furthermore, the soil was leveled to make a experimental plot with a size of $1 \mathrm{~m} \mathrm{x} 4 \mathrm{~m}$. The spacing used is $20 \mathrm{~cm} \mathrm{x}$ $15 \mathrm{~cm}$. Before planting the seeds, make a hole using a hole with a depth of $3 \mathrm{~cm}$. After planting, the seeds are covered with organic fertilizer as much as $10 \mathrm{~g}$ per planting hole. Plant maintenance includes watering, weeding and controlling plant pests. The variables observed in this study were plant height, number of leaves, number of tubers and shallot production.

\subsection{Data Analysis}

Data were analyzed using ANOVA, followed by Duncan's Multiple Range Test (DMRT) at $\alpha=0.05$ if the treatment showed a significant effect. All data analyzes were performed using Statistical Analysis Software.

\section{RESULTS AND DISCUSSION}

\subsection{Plant Height}

Inoculation of shallot seeds with rhizobacteria (seed biopriming) was significantly able to increase the height of shallot plants compared to controls. Seed inoculation with isolate CKD061 showed better plant high performance compared to control and other treatments, but was not significantly different from isolates W2R06 and isolates mixture CKD061 + W2R06, and W2R06 + TWB11. The increase in the height of shallots in the treatment of CKD061 isolate reached $12 \%$ compared to the control (Figure 1)

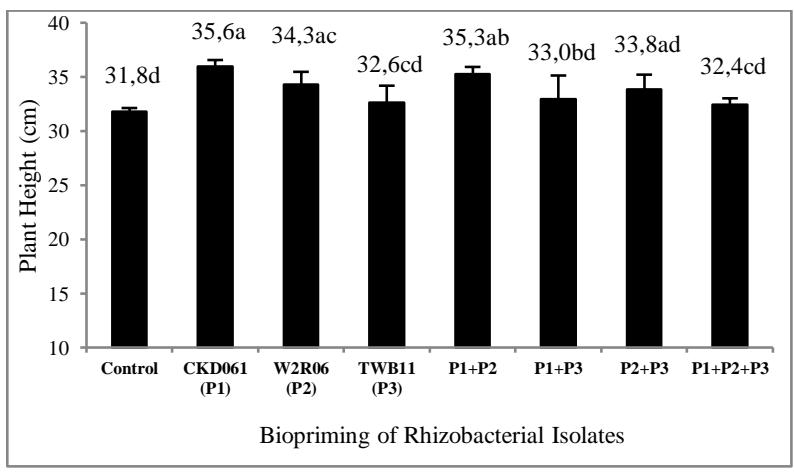

Figure 1 Effect of seed biopriming with a mixture of rhizobacterial isolates on plant height of shallot 


\subsection{Number of Leaves}

Biopriming of shallot seeds with rhizobacteria was also significantly able to increase the number of shallots compared to control. Among the treatments tested, seed inoculation with isolate CKD061 showed better leaf count performance compared to the control and isolate mixture CKD061 + TWB11, but not significantly different from other treatments. The increase in the number of shallots in the CKD061 isolate treatment reached $28 \%$ compared to the control (Figure 2).

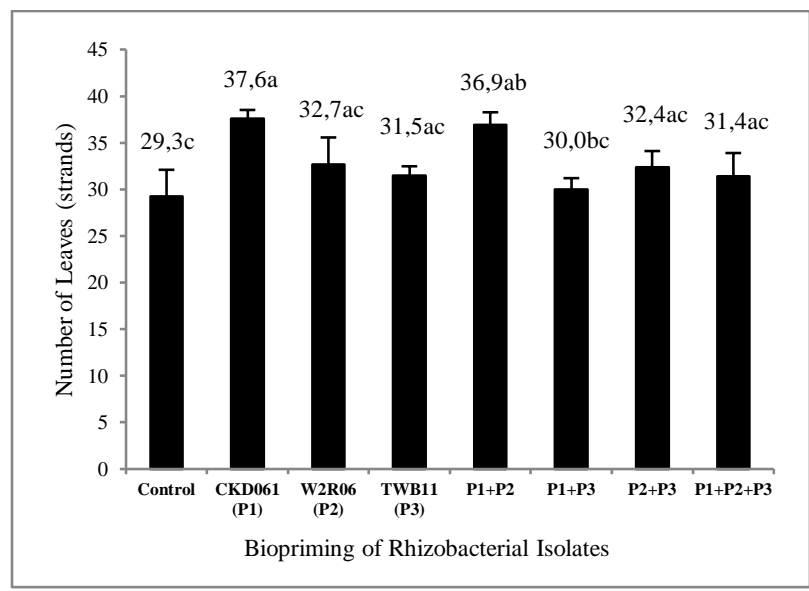

Figure 2 Effect of seed biopriming with a mixture of rhizobacterial isolates on number of leaves

\subsection{Number of Tubers}

Shallot seeds that were given biopriming treatment with rhizobacteria were also significantly able to increase the number of shallot tubers compared to the control. Among the treatments tested, seed inoculation with isolate CKD061 showed better leaf count performance compared to the control and isolate mixture CKD061 + TWB11, but not significantly different from other treatments. The increase in the number of shallot bulbs in the CKD061 isolate treatment reached 66\% compared to the control (Figure 3).

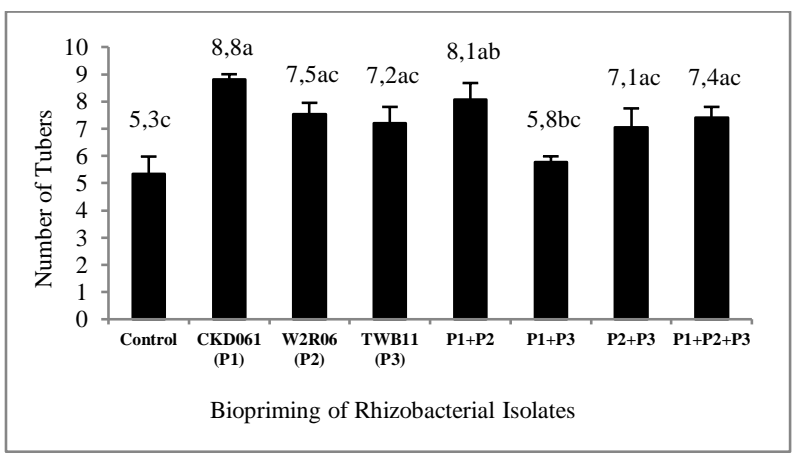

Figure 3 Effect of seed biopriming with a mixture of rhizobacterial isolates on the number of tubers

\subsection{Shallot Production}

Biopriming of shallot seeds with rhizobacteria was significantly able to increase shallot production compared to control. Inoculation of seeds with CKD061 isolate resulted in higher shallot production compared to control and other treatments, but not significantly different from the mixture of CKD061 + W2R06 isolates. The increase in shallot production in the CKD061 isolate treatment reached 68\% compared to the control (Figure 4).

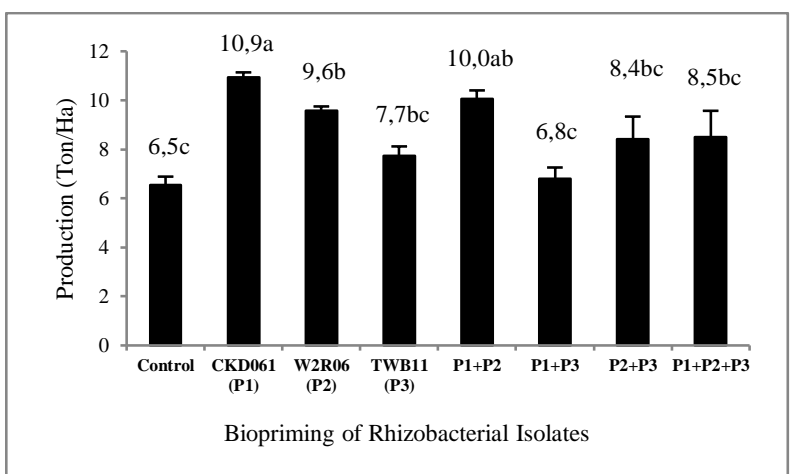

Figure 4 Effect of seed biopriming with a mixture of rhizobacterial isolates on shallot production

\subsection{Discussion}

Seed inoculation with indigenous rhizobacteria using biopriming techniques significantly increased the growth and yield of shallots compared to the control. The results of morphological and biochemical characterization showed that the rhizobacterial isolates CKD061 and W2R06 belonged to the Bacillus group, while TWB11 isolates belonged to the Pseudomonas group. Previous research results indicated that the three rhizobacterial isolates were proven to be able to stimulate plant growth [17], [18]. The role of rhizobacteria as plant growth promoters is related to their ability to dissolve phosphate, fix $\mathrm{N}$ and produce growth hormone IAA [19], [5], [20].

Several research results have proven that rhizobacteria, which are included in the PGPR (Plant Growth Promoting Rhizobacteria) group, are able to increase plant growth and yield. Both rhizobacteria from the Bacillus sp. and Pseudomonas sp. has the ability to dissolve phosphate, fix nitrogen and produce growth hormone [21], [18]. Other studies have also reported that rhizobacteria are able to increase the growth and yield of various plant commodities [22].

The results of this study indicate that the mixing of rhizobacterial isolates has not yielded the expected results. Inoculation of rhizobacteria independently actually gave better results compared to mixing. It is suspected that compatibility with one another isolates does not occur so that the excellence of each is not well expressed. This is in line with the study which states that not all mixture of isolates are able to provide a synergistic effect and give better results compared to independent applications. Among the mixture of isolates tested, only the mixture of UM96 + 
UM256 isolates showed a significant increase in root length, hypocotyl length and total fresh weight of the seeds, while the mixture of other isolates had the same effect as the control [23].

\section{CONCLUSION}

Inoculation of shallots seeds with rhizobacteria both single and mixed was more able to increase the growth and yield of shallots compared to controls. CKD061 single isolate showed better performance in increasing the growth and yield of shallots compared to other controls and isolates, but was not significantly different from mixture of CKD061 + W2R06 isolates. Increased production in the biopriming treatment of CKD061 isolates and CKD061 + W2R06 isolates respectively reached $67.69 \%$ and $53.85 \%$ compared to controls. Further testing is needed on a wider scale to get more consistent results in the field.

\section{ACKNOWLEDGMENT}

The authors extend their gratitude to the Directorate General of Higher Education Ministry of Education and Culture of the Republic of Indonesia for providing research grant under Penelitian Terapan in the fiscal year 2020 to support this study

\section{REFERENCES}

[1] Suparman, 2019, Kebutuhan bawang di Sultra masih dipasok dari luar, https://sultra.antaranews.com/berita/304848/kebut uhan-bawang-di-sultra-masih-dipasok-dari-luar.

[2] Statistik B P, 2019, Produksi Bawang Merah Menurut Provinsi, www.pertanian.go.id.

[3] Masso C Ochieng J Awuor O and B. V, 2015 Worldwide Contrast in Application of BioFertilizers for Sustainable Agriculture: Lessons for Sub-Saharan Africa J. Biol. Agric. Healthc. 5, 12 p. 34-50.

[4] Afa M Sadimantara G R Rahni N M and Sutariati G A K, 2020 Isolation \& characterization of rhizobacteria from local shallots rhizosphere as promoting growth of shallot (Allium ascalonicum L.) Int. J. Sci. Technol. Res. 9, 3 p. 3228-3233.

[5] Sutariati G A K et al., 2019 Seed biopriming with indigenous endophytic bacteria isolated from Wakatobi rocky soil to promote the growth of onion (Allium ascalonicum L.) IOP Conf. Ser. Earth Environ. Sci. 260, 1.

[6] Batool S and Iqbal A, 2019 Phosphate solubilizing rhizobacteria as alternative of chemical fertilizer for growth and yield of Triticum aestivum (Var. Galaxy 2013) Saudi J. Biol. Sci. 26, 7 p. 14001410 .

[7] M. M R. E A. B R. B and H. A E, 2017 Effect of plant growth promoting rhizobacterial (PGPR) inoculation on growth in tomato (Solanum Lycopersicum L.) and characterization for direct PGP abilities in Morocco Int. J. Environ. Agric. Biotechnol. 2, 2 p. 590-596.

[8] Ilyas S Asie K V and Sutariati G A kade, 2014 Biomatriconditioning or biopriming with biofungicides or biological agents applied on hot pepper (Capsicum annuum L.) seeds reduced seedborne Colletotrichum capsici and increased seed quality and yield ISHS Acta Hortic. 1105 p. 89-96.

[9] Widawati S and Suliasih S, 2019 Role of Indigenous Nitrogen-fixing Bacteria in Promoting Plant Growth on Post Tin Mining Soil Makara J. Sci. 23, 1 p. 28-38.

[10] Singh R K et al., 2020 Diversity of nitrogen-fixing rhizobacteria associated with sugarcane: A comprehensive study of plant-microbe interactions for growth enhancement in Saccharum spp. BMC Plant Biol. 20, 1 p. 1-21.

[11] Marques J M Mateus J R da Silva T F de Almeida Couto C R Blank A F and Seldin L, 2019 Nitrogen fixing and phosphate mineralizing bacterial communities in sweet potato rhizosphere show a genotype-dependent distribution Diversity 11, 12 p. $1-11$.

[12] Tang A Haruna A O Majid N M A and Jalloh M B, 2020 Potential PGPR properties of cellulolytic, nitrogen-fixing, phosphate-solubilizing bacteria in rehabilitated tropical forest soil Microorganisms $\mathbf{8}$, 3 p. 1-22.

[13] Olanrewaju O S Glick B R and Babalola O O, 2017 Mechanisms of action of plant growth promoting bacteria World J. Microbiol. Biotechnol. 33, 11 p. $1-16$.

[14] Martínez-Viveros O Jorquera M A Crowley D E Gajardo G and Mora M L, 2010 Mechanisms and practical considerations involved in plant growth promotion by Rhizobacteria J. Soil Sci. Plant Nutr. 10, 3 p. 293-319.

[15] Shailendra Singh G G, 2015 Plant Growth Promoting Rhizobacteria (PGPR): Current and Future Prospects for Development of Sustainable Agriculture J. Microb. Biochem. Technol. 07, 02.

[16] Bai Y Pan B Charles T and Smith D L, 2002 Coinoculation dose and root zone temperature for plant growth promoting rhizobacteria on soybean [Glycine max (L.) Merr] grown in soil-less media Soil Biol. Biochem. 34, 12 p. 1953-1957.

[17] Sutariati G A K Rakian T C Khaeruni A and Ratna, 2018 The potential of indigenous rhizobacteria isolated from wakatobi rocky soil as plant growth promoting of onions Biosci. Res. 15, 4 p. 3768 3774.

[18] Sutariati G A K Bande L O S Khaeruni A Muhidin Mudi L and Savitri R M, 2018 The effectiveness of 
preplant seed bio-invigoration techniques using Bacillus sp. CKD061 to improving seed viability and vigor of several local upland rice cultivars of Southeast Sulawesi IOP Conf. Ser. Earth Environ. Sci. 122, 1.

[19] Made Guyasa I Sadimantara G R Khaeruni A and Ayu Kade Sutariati G, 2018 Isolation of bacillus spp and pseudomonas fluorescens from upland rice rhizosphere and its potential as plant growth promoting rhizobacteria for local upland rice (Oryza sativa L.) Biosci. Res. 15, 4 p. 3231-3239.

[20] Sutariati G A K Rahni N M Madiki A Mudi L and La Fua J, 2020 Isolation and viability test of seed incorporated by indigenous rhizobacteria from areca nut as plant growth promoting rhizobacteria (PGPR) Int. J. Sci. Technol. Res. 9, 1 p. 3435-3439.

[21] Paul D and Sinha S N, 2017 Isolation and characterization of phosphate solubilizing bacterium Pseudomonas aeruginosa KUPSB12 with antibacterial potential from river Ganga, India Ann. Agrar. Sci. 15, 1 p. 130-136.

[22] Gamez R Cardinale M Montes M Ramirez S Schnell S and Rodriguez F, 2019 Screening, plant growth promotion and root colonization pattern of two rhizobacteria (Pseudomonas fluorescens Ps006 and Bacillus amyloliquefaciens Bs006) on banana cv. Williams (Musa acuminata Colla) Microbiol. Res. 220, June 2018 p. 12-20.

[23] Rojas-Solis D Hernandez-Pacheco C E and Santoyo G, 2016 Evaluation of Bacillus and Pseudomonas to colonize the rhizosphere and their effect on growth promotion in tomato (Physalis ixocarpa Brot. ex Horm.) Rev. Chapingo, Ser. Hortic. 22, 1 p. 45-57. 